\title{
Mineralogical and morphological studies of gold-bearing arsenopyrite and pyrite minerals of Bakyrchik and Bolshevik gold black shale deposits (Eastern Kazakhstan)
}

\author{
Medet Junussov $^{1^{*}}$, Zamzagul Umarbekova ${ }^{2}$ \\ ${ }^{I}$ Miskolc University, Faculty of Earth Science and Engineering/Institute of Mineralogy and Geology/Department \\ of Mineralogy and Petrology, address: H-3515 Miskolc-Egyetemváros \\ ${ }^{2}$ Satpayev University, Institute of Geology and Oil and Gas Business, Department of Geological survey, \\ prospecting and exploration of mineral deposits, address: 22 a Satpayev street, Almaty, Kazakhstan \\ "Corresponding author: medet.junus@gmail.com
}

Received: $30^{\text {th }}$ June, 2018

Accepted: $6^{\text {th }}$ July, 2018

\begin{abstract}
Bakyrchik and Bolshevik both are sediment-hosted disseminated gold deposits. They are located in Eastern Kazakhstan (4 km in distance between deposits) and include in the Western Qalba metallogenic zone. They originated in late Paleozoic age along structured line between palaeocontinents of Kazakhstan and Altai-Mongol.

The purpose of this paper is designation of typomorphic features of gold-bearing arsenopyrite and pyrite minerals, determination of chemical composition of these two sulfides minerals. The arsenopyrite and pyrite are the main objects for analytical study of gold-bearing sulfide minerals, their different textures, morphology of the crystals and aggregates. The studies of ore samples and minerals were carried out by methods of optical microscope, X-ray diffraction, X-ray fluorescence and electron microprobe analyses. The analytical study of sulphide minerals has shown that the arsenopyrite is acicular and tabular, pyrite has three varieties - globular, hexahedral and pentahedral forms in three rock samples of the carbonaceous-terrigenous formation in the deposits.
\end{abstract}

Key words: Bakyrchik, gold-bearing arsenopyrite and pyrite, acicular-prismatic arsenopyrite, cubic pyrite

\section{Introduction}

The deposits of Bakyrchik and Bolshevik have total gold reserves 207 tones and inferred resources 88 tones, with average grade $6.8 \mathrm{~g} / \mathrm{t}$. (Evgeny et al. 2017). Their location is near village of Auezov, Zharma district in Northern East Kazakhstan, $110 \mathrm{~km}$ Southeast of the Semey city and $750 \mathrm{~km}$ east of the capital city of Astana (Fig.1). The deposits have goldbearing sulfide black-shale rocks and are controlled by NW- and W-E-striking faults (Kovalev et al. 2011). The gold-containing sulfide ore minerals belong into the Bukon suite for the Middle Carboniferous Bakyrchik deposit (Umarbekova et al. 2017) and into Bakyrchik suite for Upper Carboniferous
Bolshevik deposit. Their gold mineralization is hosted within sheared carbonaceous sediments in the fault zones (Seitkan and Simon 2016). The main gold-bearing minerals are pyrite and arsenopyrite in both the deposits.

\section{The geologic and structural setting of deposits}

The most well-defined ore districts the West Qalba gold province are Bakyrchik and Semey. The Bakyrchik ore district includes gold-sulfide mineralization belonging to different associations concentrated in an area of $\sim 3500$ sq. $\mathrm{km}$. The gold-sulfide mineralization, which includes the Bakyrchik and Bolshevik deposits, 


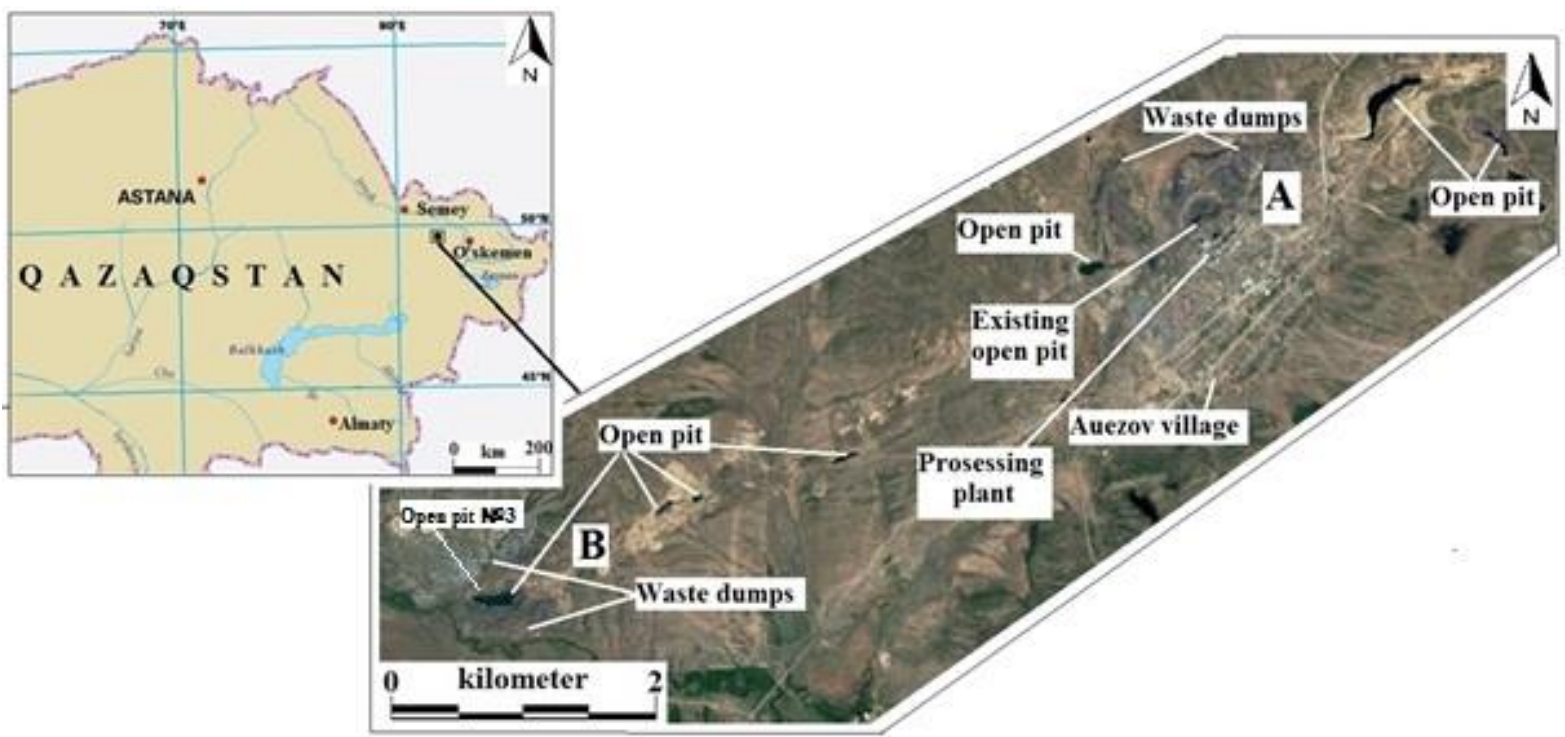

Fig.1. Overview map of the deposits of Bakyrchik (A) and Bolshevik (B). (Modified after Google Map World (left photo) and Google Earth Pro 7.3.1.4507 (32-bit) for the right photo)

are controlled by the Kyzyl EW shear zone at its conjugation with the West Qalba and Northwestern regional reverse fault (Figs 2 and 3) (Kovalev et al. 2014).

Ore mineralization along the Kyzyl shear zone from west to east and dipping to the North at $30-45^{\circ}$. The zone bounded by the West Qalba deep fault in the west and by the Northeastern deep fault in the East having 17 $\mathrm{km}$ length, 10 to $250 \mathrm{~m}$ width. According to seismic data, the zone is traced down to a depth of $1-6 \mathrm{~km}$.

\section{Bakyrchik deposit}

The ore formation is multiple conversions of syngenetic-sedimentogenic gold-bearing materials in near-fault dislocation. It is related to mineralized zone of gold-sulfide type (Umarbekova et al. 2017). All occurrences of the gold-bearing mineralization are concentrated within the Kyzyl thrust zone are intensely boudinaged and schistose host rocks. Carbonate and volcanogenic shales form the lower part of the stratigraphic sequence, which includes a $1500 \mathrm{~m}$ thick lower Carboniferous volcanoclastic sandstone containing lenses and interlayers of gritstone, conglomerate and carbonaceous-cherty siltstones. The upper part of this sequence consists of a $600-800 \mathrm{~m}$ thick sandstone unit with layers of carbonaceous siltstones, shales and a basal horizon of sedimentary breccia and conglomerate. Four stages of ore generation are detected at the well-studied Bakyrchik deposit (Kovalev et al. 2014): (1) preore silicification, carbonatization, sericitization, and graphitization of carbonaceous terrigenous rocks; (2) early ore stage connected with quartz, sericite and goldbearing arsenopyrite and pyrite; (3) polymetallic stage, during which pyrite, sphalerite, chalcopyrite, galena, grey copper ore, and native gold were accumulated; and (4) quartz-antimonite stage with quartz, marcasite, jamesonite, enargite. The gold has ultra-fine microscopic forms such as ionic and colloidal (Rafaylovich et al. 2011). The gold mineralization is localized in thin-rhythmically laminated marl, siltstones, felsic tuffs and sandstone (Fig.4). The highest amount of goldbearing arsenopyrite and pyrite is localized in siltstones. The total sulphide content of the ore varies from $0.5 \%$ to $10 \%$ (Seitkan and Simon 2016).

There are three morphogenetic various pyrites such as (1) sedimentary-digenetic globular (no gold-containing); (2) cubic form 
(gold-containing) recrystallized from globular pyrite in circumstances of high pressure and temperature and (3) pentagon dodecahedral pyrite (high gold-containing) which associates with arsenopyrite. Pyrite concentrates in chemogenic-terrigenous sediments of siliceous-argillaceous, calcareous and marl compositions (Rafaylovich et al. 2011). The arsenopyrite was formed under the condition of metagenesis and dynamo-metamorphism (Kovalev et al. 2011). The arsenopyrite content is $0.3-1.5 \%$ in the ore (Umarbekova et al. 2017). Gold grades in arsenical pyrite (1.6$5.6 \%$ of As) can reach $60 \mathrm{ppm}$ and in arsenopyrite - $150 \mathrm{ppm}$ and more (Levitan 2008).

\section{Bolshevik deposit}

The ores of the Bolshevik deposit occur in intricately dislocated Middle Carboniferous carbonaceous silty clays, sandstones, gravelstones of turbidite structure (Fig.5). Gently pitching subconcordant orebodies are 4-5 m thick, and stretch from west to east for several hundred meters, dipping for $600 \mathrm{~m}$. Ores with an average gold content of 5-7 ppm are formed by disseminated sulfide and quartzvein mineralization accompanied by silicification, sericitization, and carbonatization. Sulfides in the ores amount to $2-13 \%$; locally their content reaches $30-40 \%$. There are also disseminated, relict-layered, and massive ores at the deposit. The main types of the ores are disseminated and brecciated mineralized rocks with finely dispersed goldbearing pyrite and arsenopyrite. The relictlayered mineralized rocks contain layeredlenticular segregations of syngenetic pyrite and siderite with superposed layered arsenopyrite mineralization. The massive mineralized rocks are metasomatic $\mathrm{Fe}-\mathrm{Mg}$ carbonates with nestveinlet quartz-polysulfide mineralization. Their sulfides are sphalerite, chalcopyrite, galena, Sb-As-fahlore, Fe-Ni-Co-sulfoarsenides, and more seldom, cinnabar (Kovalev et al. 2011). The deposit represents tectonites with a vein- stockwork silicification in the zones of graphitization with pyrite and arsenopyrite sulfide mineralization(Antonov 2011). The pyrite mineral of this deposit has three varieties: they are globular pyrite (early syngenetic), widespread pentahedral pyrite associated with arsenopyrite and hexahedral pyrite associated with sphalerite, galena and chalcopyrite (Antonov 2011). Acicularprismatic arsenopyrite occurs in disseminated ores; its fine crystals (few to hundreds of microns in width) form occasional or cluster disseminations in sericitized carbonaceous siltstones and sandstones. Sometimes, the arsenopyrite occurs concordant with layered syngenetic pyrite. The core of these aggregates is usually composed of globular and finecrystalline pyrite overgrown by coarsergrained As-containing pyrite, which is, in turn, overgrown by acicular arsenopyrite (Kovalev et al. 2011).

\section{Materials and methods}

Arsenopyrite and pyrite are the main ore minerals in the studied deposits. They occur in various paragenesis and show different morphology and chemical compositions. Morphogenetic forms of pyrite and arsenopyrite crystals in the deposits are rather similar, but there are differences in shape, size and chemical concentrations. Two morphologic varieties of arsenopyrite are recognized in mineralized rock specimens: early acicular-prismatic and late tabular in both the deposits (Kovalev et al. 2011).

Gold-bearing pyrite and arsenopyrite are concentrated in or near joints and fractures, and diminish away from these structural planes. Larger strain intensity has produced more joints and fractures with resultant strong mineralization and higher gold grade (Zhiping and Stephen 1989). Low temperature arsenopyrite is mostly acicular and prismatic in form (He et al. 1993). Such arsenopyrite is characterized by high arsenic and sulfur, quite 


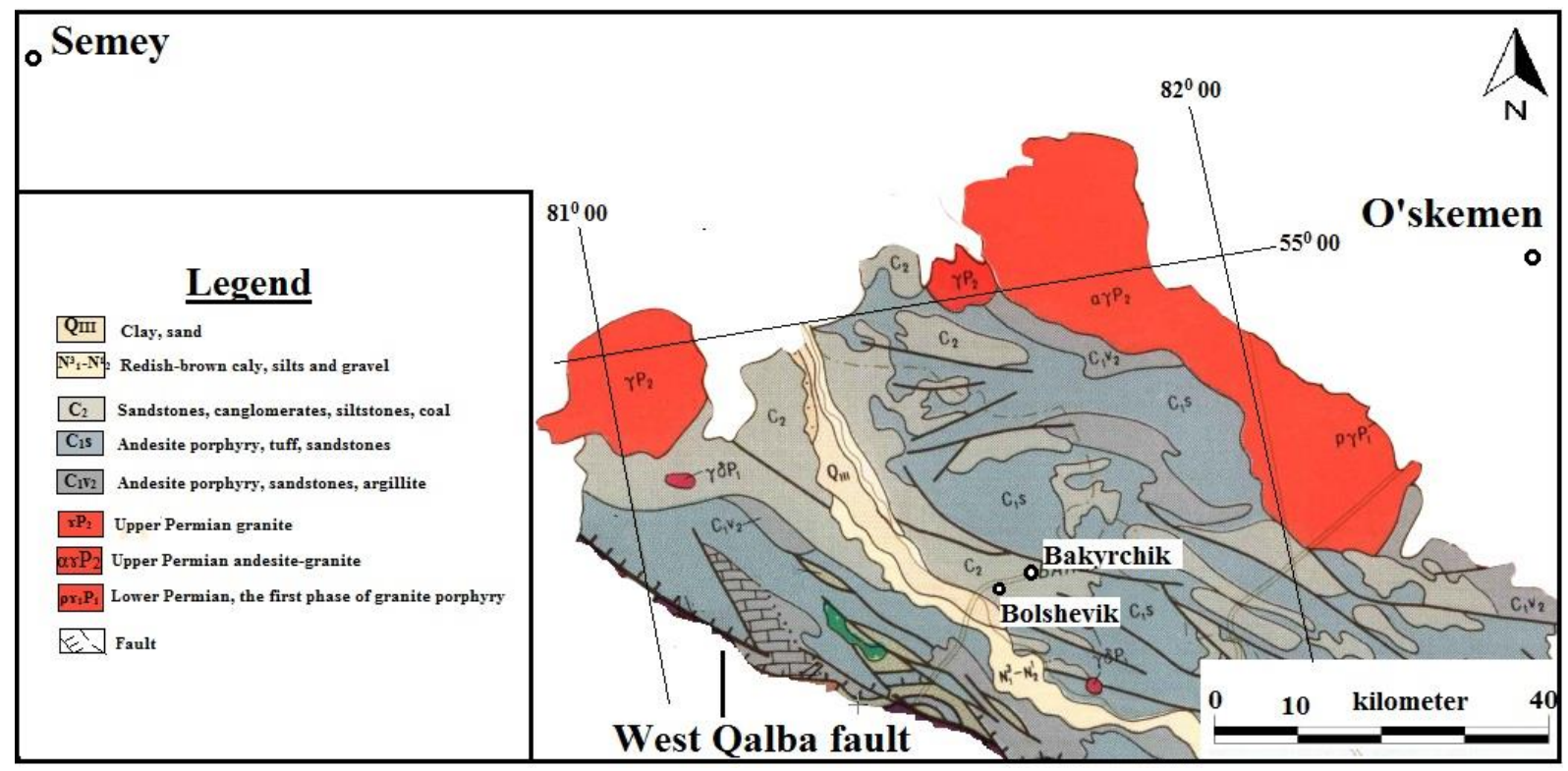

Fig.2. Geological map of the part of West Qalba province with only two deposits of Bakyrchik and Bolshevik.

(after data by I.A. Rotarash 1976)

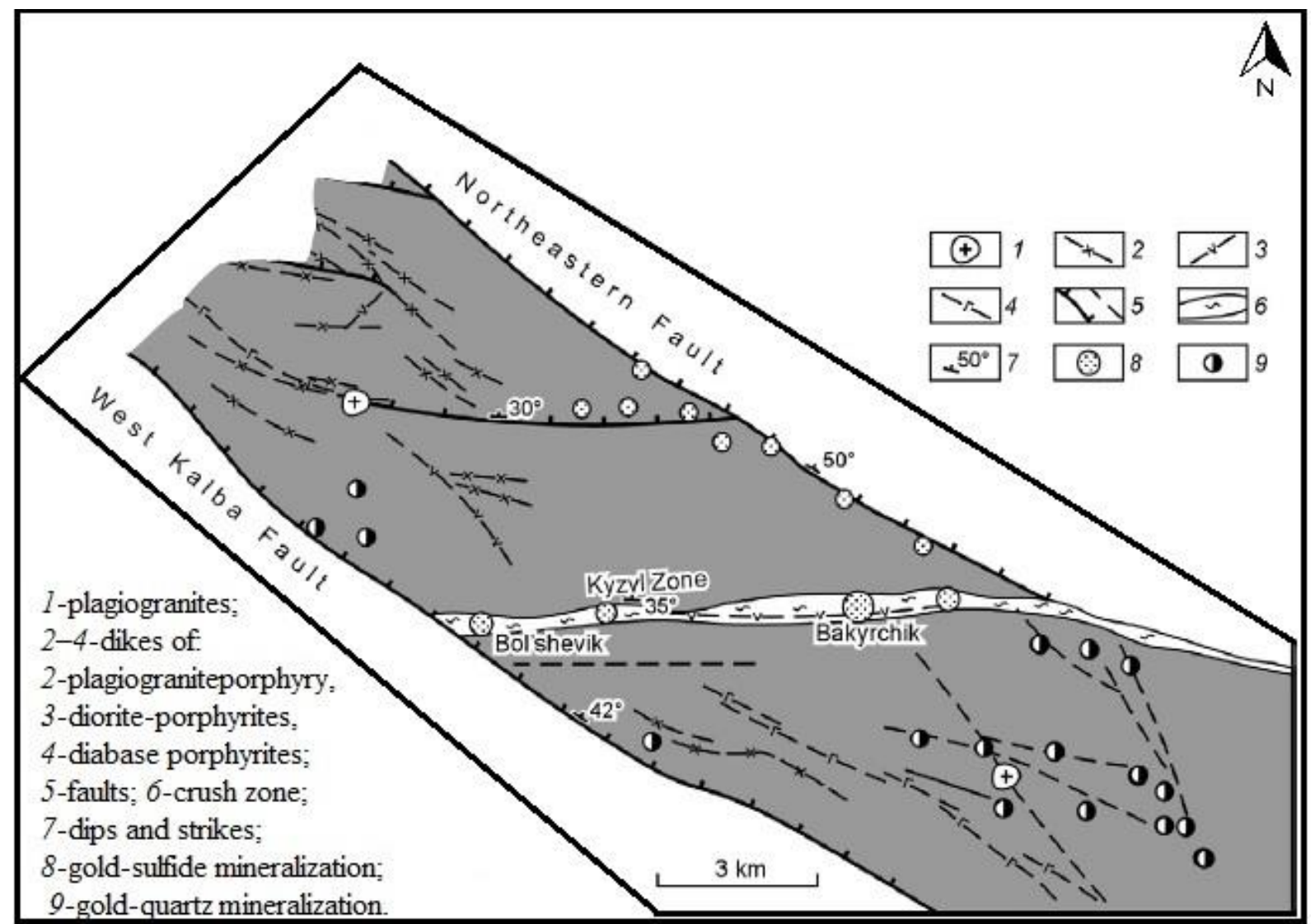

Fig.3. Schematic geologic structure of the Bakyrchik ore district (after data by G.P. Nakhtigal' Shcherba 2000 and K.R. Kovalev 2011). 


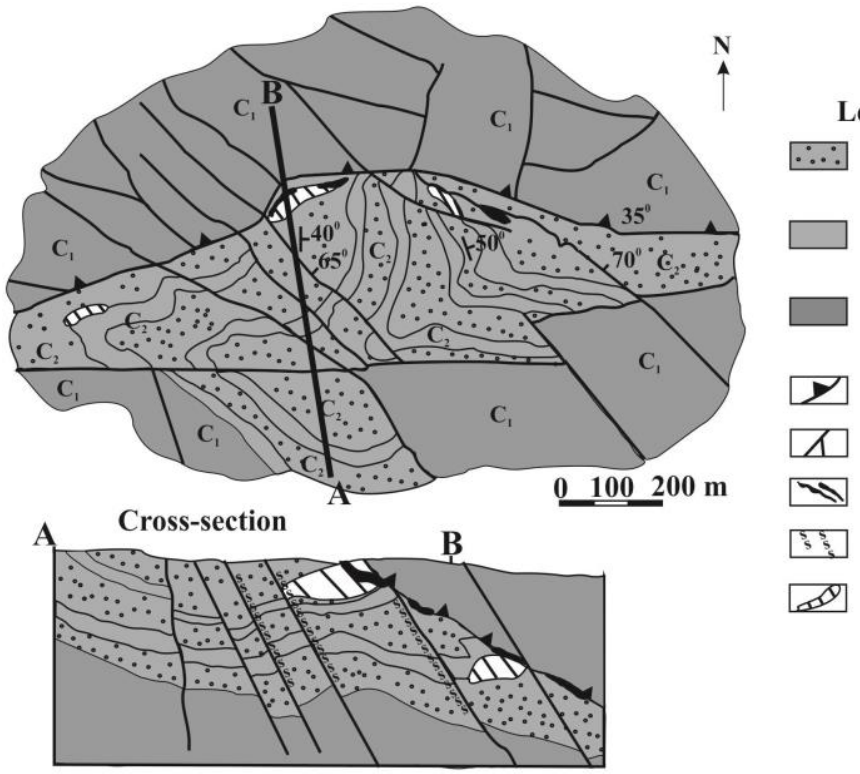

egend

Middle Carboniferous (?) carbonaceous sandstone and siltstone with interlayers of argillite and felsic tuff of molasse formation

Middle Carboniferous gold bearing carbonaceous argillite and siltstione with sulfide impregnations, siderite concretions and coal interlayers

Early Carboniferous flysh-like formation of folded

volcaniclastic sandstone, gritstone, and carbonaceous-chert siltstone

Kyzyl thrust with lenses of mylonite

Faults

Gold-sulfide-quartz along Kyzyl thrust

Zones of gold-quartz (on cross-section)

Beds of veinlets-disseminated pyrite arsenopyrite ore

Fig.4. Schematic geological model of the Bakyrchik deposit area (modified after Kurbanov 1993).

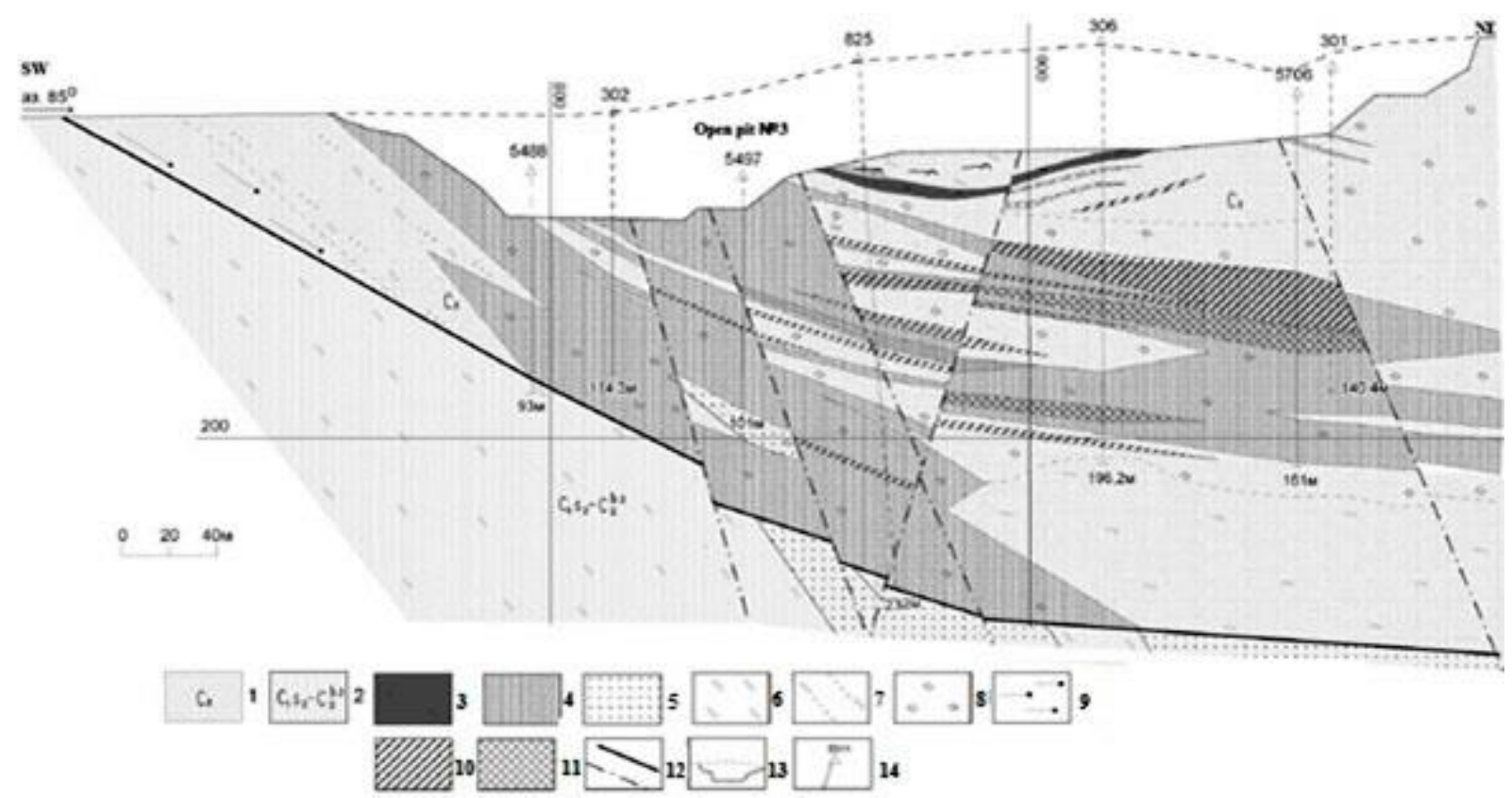

Fig.5. Bolshevik deposit: Geological cross-section of open pit №3, (after data by Antonov 2011), (the open pit №3 indicated on the overview map) 1-Bakyrchik suit; 2-siltstone-sandstone; 3-dikes: mafic and intermediate contents; 4-gold-sulfide ores (quarry border cut-off $0.3 \mathrm{~g} / \mathrm{t}$ ), 5-sandstones, 6-siltstone and shale, 7-interbedded siltstone and sandstone, 8-tectonites, 9-mylonite, 10-medium silicification (quartz 10\%-30\%); 11-intensive silicification and quartz vein (quartz more 30\%); 12-faults; 13-counter of quarry; 14-exploration well.

different from high-temperature arsenopyrite which is rich arsenic and depleted in sulfur (Shao et al. 1982). The gold-bearing arsenopyrite indicated that gold content increased with increasing As and decreasing $\mathrm{Fe}$ content in the pyrite grains (Wu et al. 1989).
Because gold is present in a metal state, it is possible that gold may substitute for $\mathrm{Fe}$ in the lattice of arsenopyrite (Wu et al.1989).

The main analytical works focus on determination of typomorphic features and elemental compositions of sulfide crystal grain 

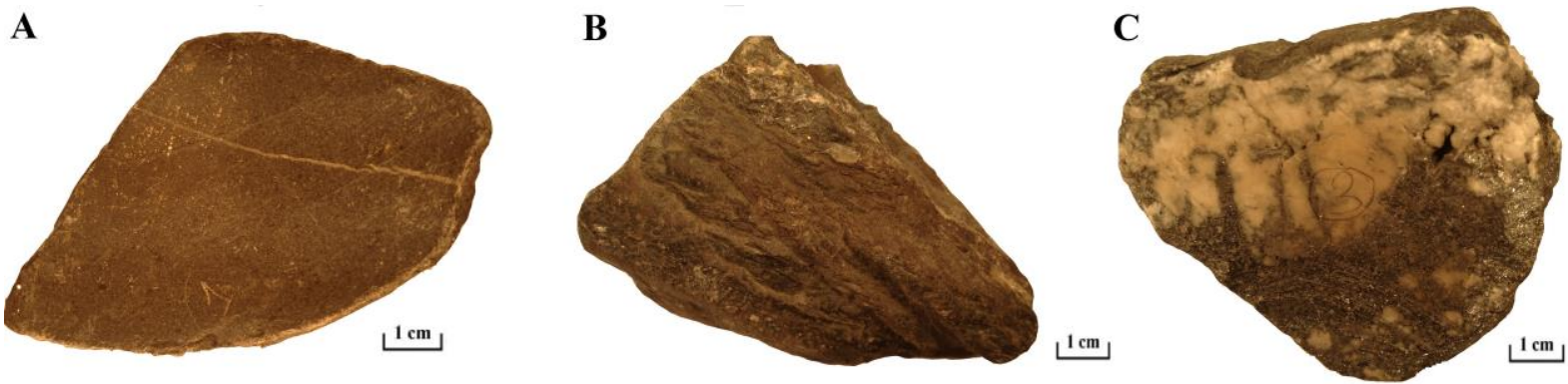

Fig.6. A - Sericizited carbonaceous-siltstone rock; $\mathbf{B}$ - Carbonaceous siltstone rock with polymetals; $\mathbf{C}$ - Sulfiderich carbonaceous siltstone with quartz-antimonite veins. (The samples of " $\mathrm{A}$ " and "B" from Bakyrchik deposit, and the "C" sample from Bolshevik deposit). (modified after a camera 5MP and Photo Shop CS3)

Tab.1. Mineralogical distribution of rock samples "A" "B" and "C"based on quantitative XRPD (BRUKER D8 ADVANCE Cu-Ka 40 kV, $40 \mathrm{~mA}$ ). Analyst Dr. F. Kristály. (Institute of Mineralogy and Geology, Miskolc University).

\begin{tabular}{|c|c|c|c|}
\hline Minerals & Sample A (Wt $\%)$ & Sample B (Wt\%) & Sample C (Wt\%) \\
\hline Muscovite & 32,8 & 20,0 & 13,7 \\
\hline Albite & 20,8 & 2,9 & 0,4 \\
\hline Quartz & 15,8 & 24,0 & 63,7 \\
\hline Amorphous & 10,0 & 14,0 & 8,0 \\
\hline Illite & 8,7 & - & - \\
\hline Siderite & 6,3 & 38,5 & - \\
\hline Ankerite & 3,3 & - & - \\
\hline Smectite & 2,4 & - & - \\
\hline Annite Mica & 0,1 & 0,6 & 3,9 \\
\hline Valentinite & - & - & 2,6 \\
\hline Pyrite & - & - & 7,7 \\
\hline Stibnite & - & - & \\
\hline
\end{tabular}

Tab.2. Chemical composition of samples of "A" "B" and "C" based on WDX-XRF (RIGAKU Supermini Pd source, 50 kV-4 mA). Analyst Dr. F.Moricz (Institute of Mineralogy and Geology, Miskolc University).

\begin{tabular}{|c|c|c|c|c|c|c|c|}
\hline $\begin{array}{l}\text { Chemical } \\
\text { elements }\end{array}$ & $\underset{(\%)}{\text { Sample A }}$ & $\begin{array}{c}\text { Sample B } \\
(\%)\end{array}$ & $\underset{(\%)}{\text { Sample C }}$ & $\begin{array}{l}\text { Chemical } \\
\text { elements }\end{array}$ & $\begin{array}{c}\text { Sample A } \\
\text { (ppm) }\end{array}$ & $\begin{array}{c}\text { Sample B } \\
(\mathbf{p p m})\end{array}$ & $\underset{(p p m)}{\text { Sample C }}$ \\
\hline $\mathrm{SiO}_{2}$ & 51,5 & 37,1 & 19,4 & $C u$ & 42 & 16 & 18 \\
\hline $\mathrm{Al}_{2} \mathrm{O}_{3}$ & 23,3 & 11,9 & 0,9 & $\mathrm{Zn}$ & 61 & 97 & $<10$ \\
\hline MgO & 0,93 & 1,92 & 0,03 & $\mathbf{P b}$ & 1304 & 835 & 336 \\
\hline $\mathrm{CaO}$ & 0,75 & 1,01 & $<0,01$ & $\mathbf{R b}$ & 76 & 20 & $<10$ \\
\hline $\mathrm{Na}_{2} \mathrm{O}$ & 1,97 & 0,27 & 0,03 & $\mathbf{S r}$ & 261 & 70 & $<10$ \\
\hline $\mathrm{K}_{2} \mathrm{O}$ & 4,02 & 2,17 & $<0,01$ & Ba & 506 & 203 & $<10$ \\
\hline $\mathrm{Fe}_{2} \mathrm{O}_{3}$ & 4,51 & 29,8 & 0,07 & As & 1537 & 956 & 346 \\
\hline MnO & 0,049 & 0,733 & $<0,005$ & $\mathrm{Cr}$ & 101 & 64 & 20 \\
\hline $\mathrm{TiO}_{2}$ & 0,878 & 0,432 & 0,006 & Co & 12 & $<10$ & $<10$ \\
\hline $\mathrm{P}_{2} \mathrm{O}_{5}$ & 0,125 & 0,504 & $<0,005$ & $\mathbf{N i}$ & 38 & 27 & $<10$ \\
\hline $\mathbf{S}$ & 0,25 & 2,6 & 26,3 & \multirow[t]{2}{*}{$\mathbf{Z r}$} & \multirow{2}{*}{222} & \multirow[t]{2}{*}{51} & \multirow[t]{2}{*}{$<10$} \\
\hline $\mathbf{F}$ & $<0.3$ & $<0.3$ & $<0,3$ & & & & \\
\hline
\end{tabular}


of arsenopyrite and pyrite as gold-bearing minerals. Three samples of sulfide-rich carbonaceous-terrigenous rocks were used (Figs 6A-6C, Tab.1 and 2) in these investigations, seven polished-sections and 3 powdered specimens. Analyses were carried out on all these samples with different methods. Namely, for determination of chemical composition X-ray fluorescence, for mineralogical composition X-ray powder diffraction, for textures of sulfidic materials in polished-sections reflected light microscope and for distribution of chemical concentrations elemental mapping by scanning electron microprobe method in interesting textures.

\section{Result and Discussion}

All micrographs are presented in Figs 7-9. The first specimen or "A" has acicularprismatic form (approximately to $1.4 \mathrm{~mm}$ in length and width less $0.2 \mathrm{~mm}$ in the Fig.9), having high sulfur and lower arsenic composition and the other one with tabular twin shape (diagonal size is $1.2 \mathrm{~mm}$ ). These morphogenetic forms were determined in large quantity in sericitized carbonaceous siltstone (the sample of " $A$ "). Additionally, more amount of acicular-prismatic arsenopyrite associates with hexahedral pyrite crystals which is related to Bakyrchik deposit, whereas other tabular arsenopyrite associates (from the sample of "C") with cubic (pentahedral) pyrite crystals which are belong to Bolshevik deposit (Fig.8). The tabular arsenopyrite in the sample " $\mathrm{C}$ " is smaller size: in the length $0.01 \mathrm{~mm}$ and $0.008 \mathrm{~mm}$ in the width (Fig.8). This shape of arsenopyrite crystal is not twinned like in the samples of Bakyrchik. The acicular-prismatic form of arsenopyrite in sample of Bolshevik (the sample " $\mathrm{C}$ ") is too small size in length $0.08 \mathrm{~mm}$ and in width $0.01 \mathrm{~mm}$ (Fig.8).

The pyrite textures appear in three various forms (Fig.7) which were found under microscope in several polished samples from the three specimens. Especially, their distributions are connected to sample " $\mathrm{B}$ " which is a carbonaceous siltstone rock with polymetals. The first textural type of pyrite is framboidal aggregate and its size is mostly more than $50 \mu \mathrm{m}$ in sample, appearing in sericitized carbonaceous siltstones (Fig.7). Another two forms are pentahedral and hexahedral pyrite crystals. Hexahedral pyrite crystal is found in sample of " $\mathrm{B}$ " and pentagonal spreads in composition of rock sample of " $A$ " in the deposit of Bakyrchik.

There are two pyrite crystal forms in the sample of "C" in Bolshevik, having globular and cubic crystals. The diameter of globular pyrite crystals are $0.25 \mathrm{~mm}$ and cubic crystal is 0.02-0.04 mm. The cubic crystal associates with tabular arsenopyrite (Fig.8).

Quantitative analysis of elemental concentration was done by indication of points in interesting arsenopyrite and pyrite grains of the samples. 15 points were indicated in acicular-prismatic and 15 points in tabular forms for the sample "A". The pyrite pentahedral crystal has 10 points and combination two forms of acicular arsenopyrite and pentahedral pyrite crystals have 6 points which are both related to the samples "A". The sample "B" has 9 points in the shape of hexahedral pyrite crystal. In the sample "C" of Bolshevik also several points was measured on the surface of interesting crystal forms of sulfide minerals: there are 5 points in tabular form of arsenopyrite, 3 points in cubic pyrite crystal grain and for acicularprismatic crystal form of arsenopyrite 4 points. The iron and arsenic elements have stable concentrations. Other elements are absent and no gold inclusions are found in sulfide crystals (Fig.9).

Arsenopyrite and pyrite (As-bearing pyrite, As 0.97-4.86 wt\%, Tab.3) are the main goldcontaining minerals in the studied deposits of Bakyrchik and Bolshevik. Two morphologic varieties of arsenopyrite are recognized in mineralized rocks: acicular-prismatic and tabular for both deposits. Three pyrite crystal 

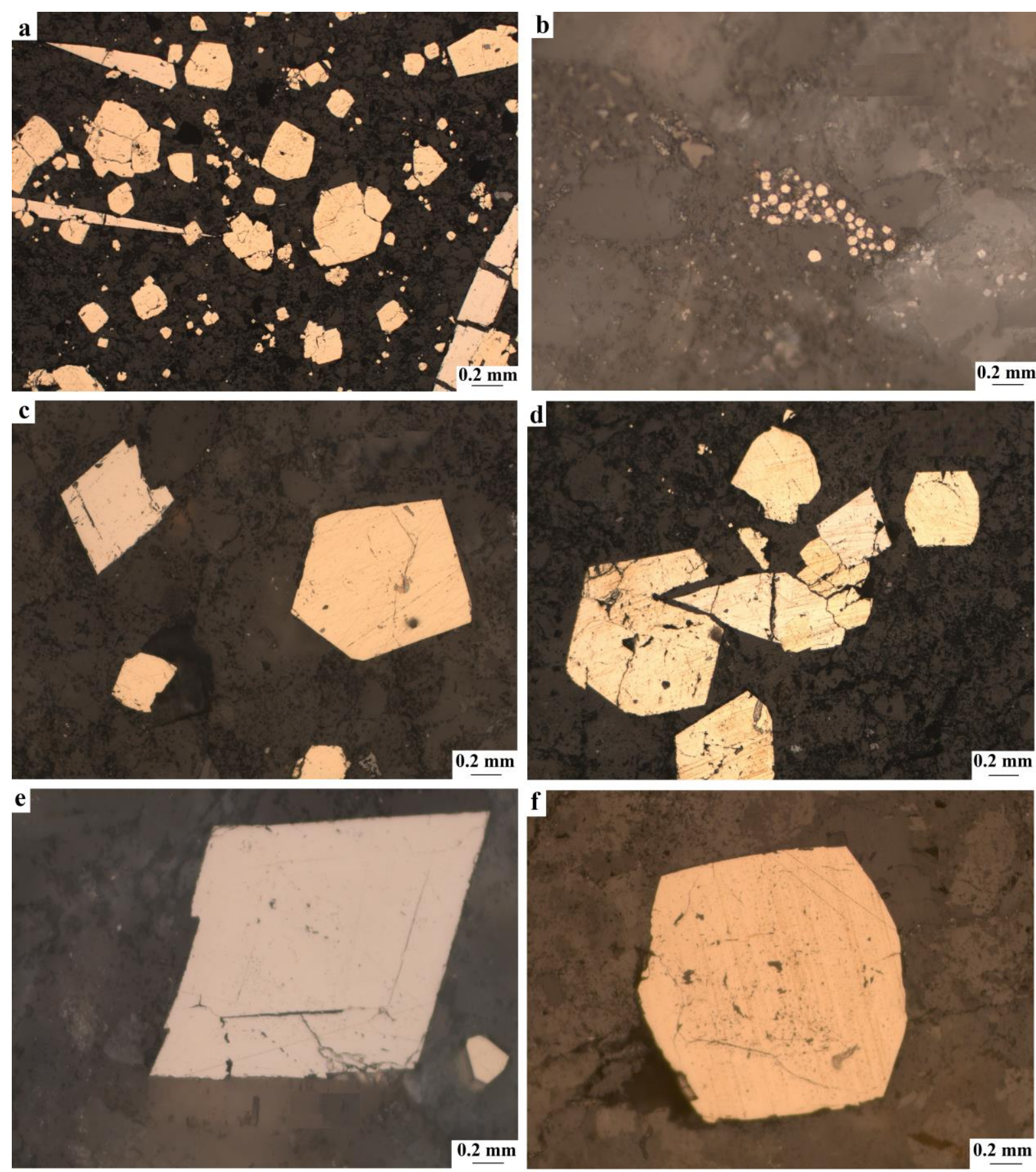

Fig.7. Reflected light micrographs. Bakyrchik deposit: Rock sample of "A": (a) Hexagonal pyrite crystal with acicular-prismatic arsenopyrite; (b) Pyrite framboidal aggregate; (c) Pentagonal pyrite cross-sections and tabulararsenopyrite twin; (d) hexahedral pyrite in growth with tabular arsenopyrite; (e) Tabular-arsenopyrite twin. Rock sample of "B": (f) Hexagonal crystal of pyrite. Analyst M.Junussov (Institute of Mineralogy and Geology, Miskolc University)

forms are hexahedral, cubic and globular associated with deposits. They differ in chemical composition the set of impurity elements, similar in mineralogical composition, and no gold content in the samples of the deposits. The acicular-prismatic arsenopyrite and globular pyrite occur in mineralized rocks produced at the early ore formation stage in the deposits, both as disseminated mineralization and densely 
Tab.3. Elemental concentration (wt \%) in textures of gold-bearing sulfide minerals (no presence of gold) measured by EDS (SEOL SXA 8600 Superprobe, $20 \mathrm{KeV}$ and $20 \mathrm{~mA}$ ). Analyst L. Mátè

(Institute of Mineralogy and Geology, Miskolc University)

\begin{tabular}{|c|c|c|c|c|c|c|}
\hline Deposits & Samples & Morphology of sulfide minerals & Number & $\mathrm{S}$ & $\mathrm{Fe}$ & As \\
\hline \multirow{55}{*}{ 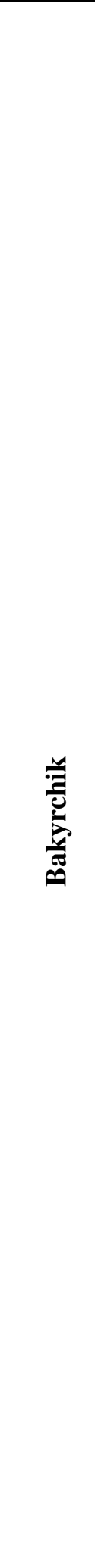 } & \multirow{46}{*}{ A } & \multirow{15}{*}{ Acicular-prismatic arsenopyrite } & 1 & 21.66 & 31.04 & 47.30 \\
\hline & & & 2 & 21.72 & 31.20 & 47.08 \\
\hline & & & 3 & 21.65 & 31.11 & 47.24 \\
\hline & & & 4 & 21.56 & 31.28 & 47.16 \\
\hline & & & 5 & 21.79 & 31.09 & 47.13 \\
\hline & & & 6 & 21.37 & 31.25 & 47.38 \\
\hline & & & 7 & 21.80 & 31.08 & 47.12 \\
\hline & & & 8 & 21.73 & 30.92 & 47.36 \\
\hline & & & 9 & 21.92 & 31.20 & 46.89 \\
\hline & & & 10 & 22.97 & 31.57 & 45.46 \\
\hline & & & 11 & 23.62 & 31.97 & 44.41 \\
\hline & & & 12 & - & - & - \\
\hline & & & 13 & 23.19 & 31.41 & 45.41 \\
\hline & & & 14 & 22.69 & 31.57 & 45.75 \\
\hline & & & 15 & 21.99 & 31.33 & 46.68 \\
\hline & & \multirow{15}{*}{ Tabular arsenopyrite } & 1 & 22.12 & 30.39 & 47.48 \\
\hline & & & 2 & 21.53 & 30.08 & 48.39 \\
\hline & & & 3 & 21.61 & 30.37 & 48.02 \\
\hline & & & 4 & 22.13 & 30.46 & 47.41 \\
\hline & & & 5 & 21.93 & 30.61 & 47.46 \\
\hline & & & 6 & 21.96 & 30.52 & 47.52 \\
\hline & & & 7 & - & - & - \\
\hline & & & 8 & 22.57 & 30.40 & 47.02 \\
\hline & & & 9 & 22.31 & 30.57 & 47.12 \\
\hline & & & 10 & 22.98 & 30.53 & 46.49 \\
\hline & & & 11 & - & - & - \\
\hline & & & 12 & 22.05 & 30.18 & 47.77 \\
\hline & & & 13 & 22.00 & 30.43 & 47.57 \\
\hline & & & 14 & - & - & - \\
\hline & & & 15 & 22.91 & 30.24 & 46.85 \\
\hline & & \multirow{10}{*}{ Pentahedral pyrite } & 1 & 54.53 & 42.76 & 2.71 \\
\hline & & & 2 & 54.21 & 42.36 & 3.43 \\
\hline & & & 3 & 54.10 & 42.48 & 3.42 \\
\hline & & & 4 & 54.11 & 42.48 & 3.41 \\
\hline & & & 5 & 55.60 & 42.60 & 1.81 \\
\hline & & & 6 & 53.88 & 42.18 & 3.94 \\
\hline & & & 7 & 54.89 & 42.67 & 2.44 \\
\hline & & & 8 & 53.74 & 42.58 & 3.68 \\
\hline & & & 9 & 54.26 & 42.50 & 3.25 \\
\hline & & & 10 & 54.73 & 42.78 & 2.50 \\
\hline & & \multirow{6}{*}{$\begin{array}{l}\text { Combination of acicular-prismatic } \\
\text { arsenopyrite and pentahedral pyrite }\end{array}$} & 1 & 22.18 & 31.12 & 46.70 \\
\hline & & & 2 & 22.86 & 32.08 & 45.05 \\
\hline & & & 3 & 54.19 & 43.65 & 2.16 \\
\hline & & & 4 & 53.94 & 43.45 & 2.61 \\
\hline & & & 5 & 54.11 & 43.55 & 2.33 \\
\hline & & & 6 & 53.53 & 43.64 & 2.83 \\
\hline & \multirow{9}{*}{$\mathrm{B}$} & \multirow{9}{*}{ Hexahedral pyrite } & 1 & 53.65 & 42.92 & 4.43 \\
\hline & & & 2 & 53.09 & 43.05 & 3.86 \\
\hline & & & 3 & - & - & - \\
\hline & & & 4 & 53.36 & 43.09 & 3.55 \\
\hline & & & 5 & 52.10 & 43.03 & 4.86 \\
\hline & & & 6 & - & - & - \\
\hline & & & 7 & 52.81 & 43.36 & 3.83 \\
\hline & & & 8 & 53.40 & 43.16 & 3.44 \\
\hline & & & 9 & 53.98 & 43.31 & 2.70 \\
\hline
\end{tabular}


Tab.3. Continued

\begin{tabular}{|c|c|c|c|c|c|c|}
\hline \multirow{12}{*}{$\frac{y}{\frac{a}{2}}$} & \multirow{12}{*}{$\mathrm{C}$} & \multirow[t]{5}{*}{ Tabular arsenopyrite } & 1 & 22.11 & 32.00 & 45.89 \\
\hline & & & 2 & 22.36 & 32.30 & 45.34 \\
\hline & & & 3 & 23.56 & 33.02 & 43.42 \\
\hline & & & 4 & 22.50 & 32.40 & 45.09 \\
\hline & & & 5 & 21.99 & 32.16 & 45.85 \\
\hline & & \multirow[t]{3}{*}{ Cubic pyrite } & 1 & 53.21 & 43.75 & 3.05 \\
\hline & & & 2 & 53.50 & 43.91 & 2.59 \\
\hline & & & 3 & 54.82 & 44.20 & 0.97 \\
\hline & & \multirow{4}{*}{ Acicular-prismatic arsenopyrite } & 1 & 24.20 & 32.09 & 43.71 \\
\hline & & & 2 & 23.72 & 32.45 & 43.84 \\
\hline & & & 3 & 22.61 & 31.18 & 46.22 \\
\hline & & & 4 & 22.69 & 31.65 & 45.66 \\
\hline
\end{tabular}
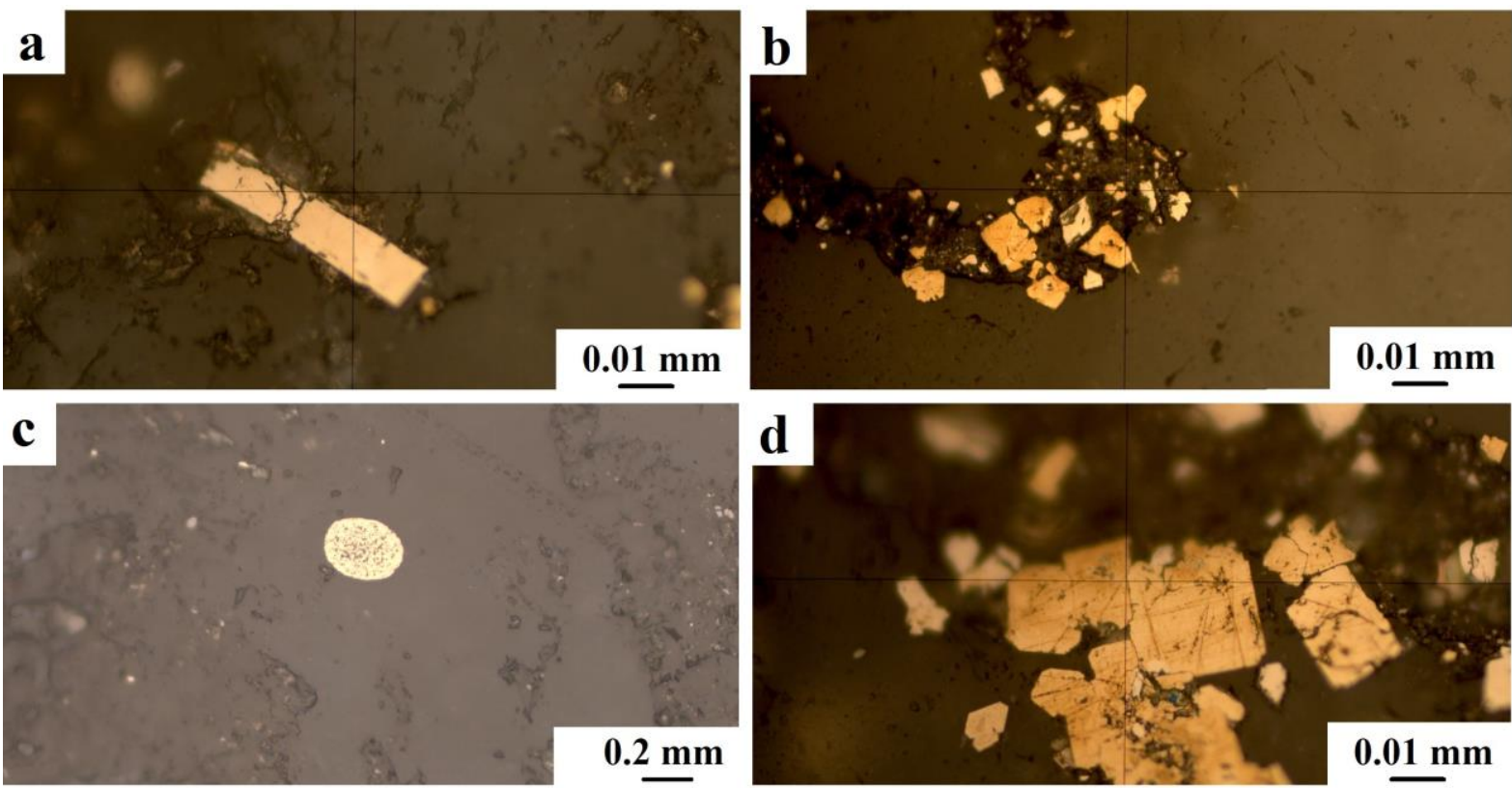

Fig.8. Reflected light micrographs. Bolshevik deposit: (a) acicular-prismatic arsenopyrite; (b) Tabular arsenopyrite and acicular arsenopyrite integrated to cubic pyrite crystals; (c) Globular pyrite; (d) cubic pyrite crystals associated with tabular arsenopyrite. Analyst M. Junussov (Institute of Mineralogy and Geology, Miskolc University)

disseminated clusters, forming layers in carbonaceous siltstones. The difference of ore mineral composition between Bakyrchik and Bolshevik deposits, Bakyrchik has simple ore formation whereas the Bolshevik is typical antimonite-containing deposit (stibnite and valentinite) excluding arsenopyrite and pyrite. The antimonite-containing minerals were measured and shown in Table 1.

The chemical concentration of antimonite was sufficiently high in the sample of " $\mathrm{C}$ " and it was difficult to show antimonite concentration by XRF.
The textures of gold-bearing minerals enable simple orientations to predict gold presence or signs. Perhaps, they may indicate actual places for prognosis of gold existence in a sample by textural features of sulfide minerals in the field before micro-analytical investigations at laboratory. The results of mineralogical composition and their morphology, crystal sizes and chemical composition of individual textures of goldsulfide minerals show that the size of sulfide mineral textures are visual accessibility to indicate their presence in specimen materials 

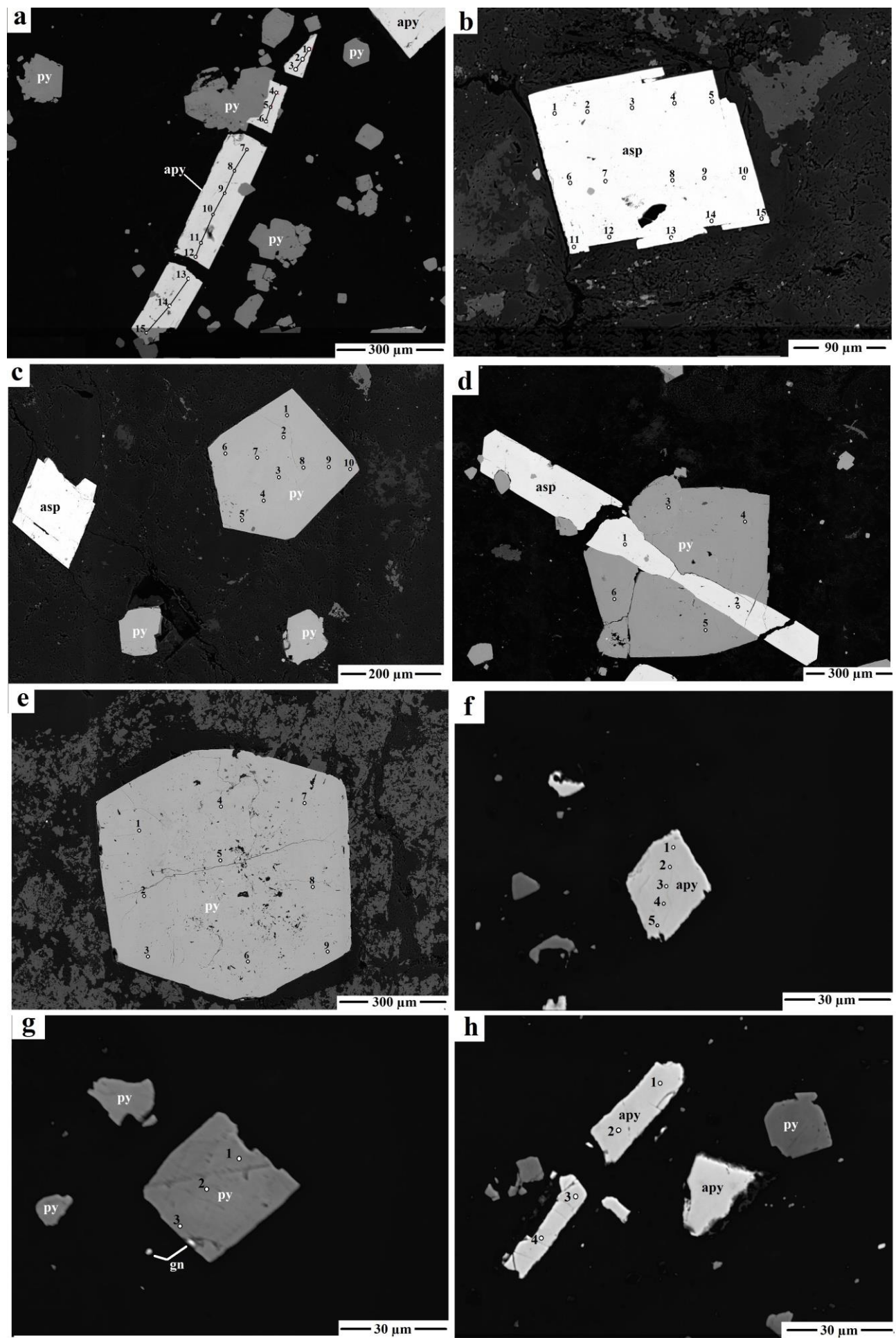

Fig.9. Micrographs of sulfide minerals with points for elemental measurement. The deposit of Bakyrchik: sample "A" - a) acicular-prismatic arsenopyrite associated with cubic pyrite crystals, b) tabular-arsenopyrite twin, c) pentahedral pyrite crystal with tabular-arsenopyrite twin, d) integration of acicular-prismatic arsenopyrite and pentahedral pyrite crystal; Sample "B" - e) hexahedral pyrite crystal. The deposit of Bolshevik: sample "C" - f) tabular arsenopyrie crystal, g) cubic pyrite crystal with galena inclusion, h) acicular-prismatic arsenopyrite with crystals of cubic pyrite. (apy-arsenopyrite, py-pyrite, gn-galena) They measured by EDS (SEOL SXA 8600 Superprobe, $20 \mathrm{KeV}$ and $20 \mathrm{~mA}$ ). Analyst L. Mátè (Institute of Mineralogy and Geology, Miskolc University) 


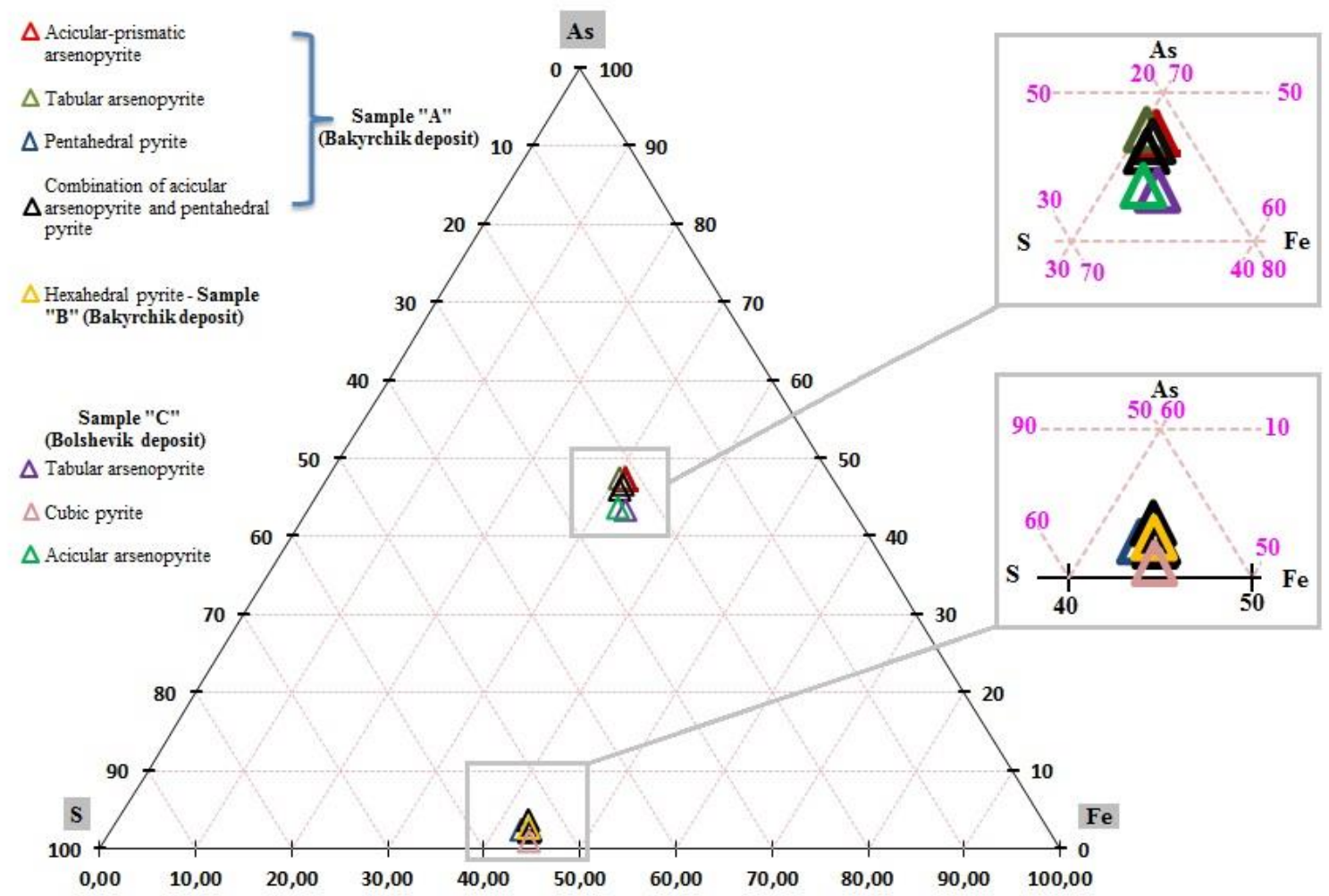

Fig.10. Triangular scheme of elemental concentrations (S-Fe-As) for sulfide minerals with texture differentiation. (Compiler M. Junussov)

without a special equipment, and required further investigation for gold inclusions within sulfide minerals.

\section{Conclusion}

During the optical investigation of textures of sulfide minerals were shown the textures (Fig.10) for arsenopyrite are acicular-prismatic and tabular, textures for pyrite are globular, hexahedral and pentahedral forms in the deposits (Fig.10). Each ones have individual interests in textures and chemical concentrations for gold inclusions in arsenopyrite and pyrite minerals. No gold inclusions have found in the samples of " $\mathrm{A}$ " " $\mathrm{B}$ " and " $\mathrm{C}$ " in the studied deposit by optical microscope and scanning electron microprobe. Therefore, the ore materials of the deposits of Bakyrchik and Bolshevik from the point of view gold prospecting is rather complex, they have double persistence in arsenopyrite (like a toxic arsenic element) and disseminated gold in colloidal size. Relatively, in this case it requires additional highly sensitive equipment and reliable methods for indication of gold presence in the samples.

\section{Acknowledgments}

I thank Z.T. Umarbekova for the opportunity of sharing with sample collections. Also, my special thanks go to Dr. F.Madai for consultation and patience; and. L. Mátè (EMPA), Dr. F. Kristály (X-Ray diffraction), Dr. F.Moricz (X-Ray Flouresence) for their helps with analytical works.

\section{References}

Antonov Yu.A. (2011) Gold ore mineralization of Bolshevik deposit in structurallithological localizations (Strukturnolotologisheskye zakonomernosty 
lokalizacy zolotovo orudnenya mestorozhedya Bolshevik). Dissertation, Polytechnic University of Tomsk.

Evgeny N., Alexander B., Yuri K., Konstantin K., Boris D., Marina M., and Reimar S. (2017) Permian orogenic gold deposits of Eastern Kazakhstan and Western Siberia. SEG 2017, 115.

He, Lixian, Zen, Ruelan and Lin, Liqing. (1993) Geology of Guizhou Gold Deposits. Geochemistry 15, 2, 189-192

Kovalev K.R., Kalinin Yu.A., Naumov E.A., Kolesnikova M.K., Korolyuk V.N. (2011) Gold-bearing arsenopyrite in eastern Kazakhstan gold-sulfide deposits, Russian Geology and Geophysics 52, 178-192

Kovalev K.R., Kalinin Yu.A., Naumov E.A., Myagkaya M.K. (2014) Relationship of antimony with gold mineralization in the ore districts of Eastern Kazakhstan, Russian Geology and Geophysics 55, 1170-1182

Levitan G. (2008) Sediment-hosted gold and gold-silver deposits. [In:] Gold deposits of the CIS. USA Press, 91-95

Rafaylovich S., Myzernaya M.A., D’yachkov B.A. (2011) Giant gold deposits in black shale formations: origin and similarity (Krupnye mestorozhdenya zolota $\mathrm{v}$ chernoslancevyz tolshah: uslovya formirovanya, pryznaky shodstva) (in Russian). Luxe Media Group Press. First edition.

Seitkan A., Simon A.T. Redfern. (2016) Processing double refractory gold-arsenicbearing concentrates by direct reductive melting. Minerals Engineering, 98, 1-17, DOI:0.1016/j.mineng.2016.08.017

Shao, Jielian, Xu, Guofeng, Feng, Shuzhuang, $\mathrm{Lu}$, Ruiying and Mei, Jianming.(1982) Study of a pyrite of a Carlin-type gold deposit in Shannxi, China (in Chinese): Acta-Petrologica. Mineralogica. et Analytica., 1, 2, 25-35.

Umarbekova Z.T., Dyusembayeva K.S., Kubashev K.T. (2017) The Bakyrchik deposit and views on the formation of the mineral deposits in black shale beds. SGEM 17, 11, 1111-1117.

Wu, Xin and others. (1989) Hydrothermal synthesis of gold-bearing arsenopyrite: Geol. 84, 2029-2032

Zhiping Li and Stephen G.Peters. (1998) Comparative Geology and Geochemistry of sedimentary-rock-hosted (Carlin type) gold deposits in the people's Republic of China and in Nevada, USA., Open-file report 98-446 